\title{
PSYCHE
}

VOL. XXI.

AUGUST, 1914.

No. 4

\section{HYBRID BUTTERFLIES OF THE GENUS BASILARCHIA.}

\author{
By W. L. W. Field, \\ Milton, Massachusetts.
}

On August 19, 1910, at Alstead Center, New Hampshire, several females of Basilarchia archippus, reared in captivity, were placed in a breeding-cage with males of $B$. arthemis captured in the neighborhood. The butterflies were fed with dilute honey applied to heads of Prunella and clover.

On August 20, a pair was found in copulation, remaining in that state for about half an hour. Afterward the female was removed from the cage and placed on willow shoots out-of-doors, under a cheese-cloth covering. Every leaf of the willow had been inspected; a wooden baseboard was provided, and all crevices were tightly packed with cotton. The butterfly was a crippled one, and found difficulty in balancing herself upon the leaves. Some of her eggs were laid upon leaves in the normal way, a few on stems, and many on the cheese-cloth in the vicinity of the foliage. In seven days she laid sixty-two eggs, and then died.

The larvæ began hatching nine days after the beginning of oviposition, but in all only nineteen appeared; and it was noted that none of these came from eggs laid toward the end of the period of oviposition.

The larvæ grew slowly, but were favored by unusually mild weather, and began to construct hibernacula early in October. On October 21, sixteen were found hibernating; the others had disappeared. The hibernating larvæ were transferred to a small outdoor shelter near my laboratory in Milton, Mass.

On April 27, 1911, they were placed on willow shoots under a cheese-cloth shelter. The willow shoots had been started indoors and kept under close scrutiny, and were known to be free from other larvæ.

On May 7 , the larvæ began to issue from their hibernacula. In all ten appeared, but one was very belated and weak, and soon 
died. One other was injured by a fall after pupating, and died. Eight, all males, reached the imago stage successfully. The small size of the pupa which died warranted the surmise that it, also, was a male.

The butterflies were all closely like the type specimen of arthechippus in the Museum of Comparative Zoölogy, described by Scudder (1889), and the two specimens captured on the wing in Alstead, N. H., and deposited in the same collection. The older specimens are likewise all males.

Diligent efforts were made to mate these butterflies with females of allied species. Arthemis, archippus, astyanax and proserpina were all tried, in different breeding cages and in various numbers and groupings, but no mating occurred. Both sexes, however, in several instances showed marked sexual excitement, and their failure to copulate is probably to be ascribed to some unfavorable element in the illumination of the cages at critical moments.

On August 30, 1910, at Alstead Center, a female Basilarchia astyanax, reared in captivity from a larva obtained near Brooklyn, N. Y., mated with a male arthemis captured in Alstead. The duration of copulation was fifty-five minutes. The female was afterward imprisoned over carefully-inspected wild cherry shoots, on the leaves of which she deposited eighty-two eggs. Oviposition was begun on September 5, and extended over nine days.

The eggs were extremely slow in hatching, and no exact count of the young larvæ was obtained. Forty-one survived the early frosts, and the construction of hibernacula began on October 21. The hibernating larvæ were kept through the winter in an outdoor shelter in Milton, Mass., and bagged out on inspected shoots of wild cherry April 27, 1911. On May 7 they began to emerge from their nests, but their number had dwindled to ten when the count was made. All of the ten pupated successfully, but only eight reached the imago state: five males and three females, all rather dark examples of proserpina.

Efforts to breed these butterflies with one another were unsuccessful. Attempts were then made to mate them with arthemis and astyanax, the two parent species; and the females were introduced into the boxes containing the males of arthechippus, already described; but no copulation occurred. 
The accompanying plate shows a male and a female of proserpina, and two males of arthechippus, chosen from the two series just described. These specimens, with others more worn and disfigured by their prolonged detention in the breeding cages, are in the Museum of Comparative Zoölogy at Harvard University. The tattered remains of the parents of both broods will be found in the same case.

Publication of this record has been delayed in the hope of obtaining new hybrids and breeding them to further generations; but though success seemed very close in the experiments of 1912 and 1913, no progress has been made. The work has been resumed with abundant material, and the present summer may witness some definite results. At all events, the hybrid character of arthechippus and proserpina is now established; and observations already published (Field, 1910) make it clear that proserpina will at least breed with one of the parent species. Increased interest thus attaches to the butterflies of this always interesting genus.

Bateson, W.

BIBLIOGRAPHY.

1913. Problems of Genetics. New Haven: Yale University Press.

Field, W. L. W.

1904. Problems in the genus Basilarchia. Psyche, xi, 1-6, 3 pl.

1910. The offspring of a captured female Basilarchia proserpina. Psyche, xvii, 87-89, 1 pl.

Scudder, S. H.

1889. The Butterflies of the Eastern United States and Canada, with special reference to New England. Cambridge: published by the author.

Note on Linognathus forficula Kellogg and Paine.

Through recent correspondence with H. Fahrenholz of Hannover, Germany, an active worker with the Anoplura, the writer has received information which concerns the nomenclature of Linognathus forficula, described by Kellogg and Paine from Cervicapra arundinum. ${ }^{1}$ The generic position of Rudow's Homatopinus forficulus ${ }^{2}$ has, on account of an insufficient description, been considered doubtful. However, Fahrenholz has come into possession of a series of specimens of Rudow's species which reveals the fact that it must be placed in the genus Linognathus. The name $L$. forficula, therefore, as applied to Kellogg and Paine's species, must give way, on account of priority, and is herewith substituted by the name Linognathus fahrenholzi.

J. H. Paine.

\footnotetext{
1 Kellogg, V. L. and Paine, J. H. Anoplura and Mallophaga from African Hosts; Bull. Ent. Research, Vol. II, p. 147, July, 1911.

2 Rudow, Zeitschr. f. gew. Naturw. Vol. 34, p. 169 (1869).
} 


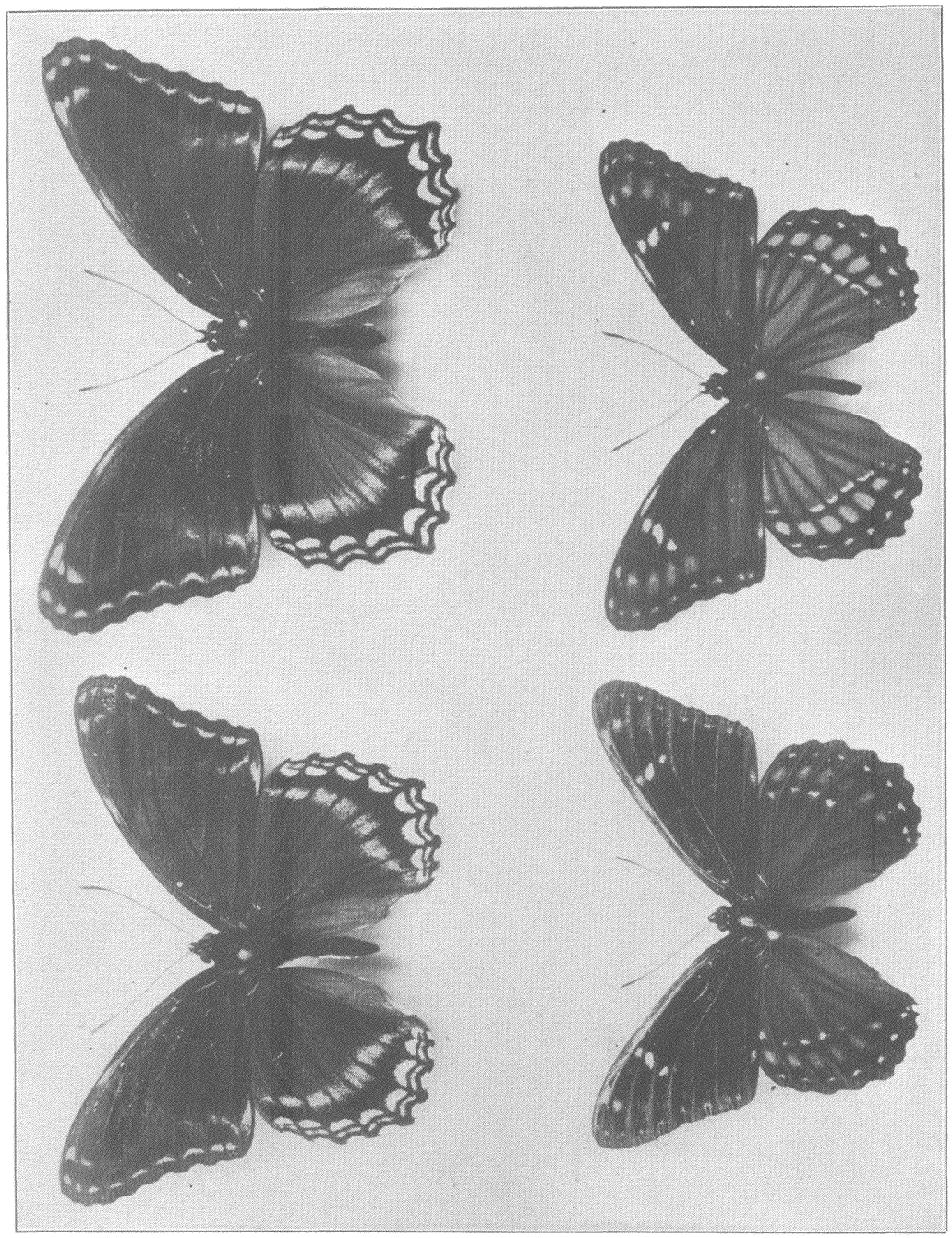

Field-Butterflies of the Genus Basilarchia. 

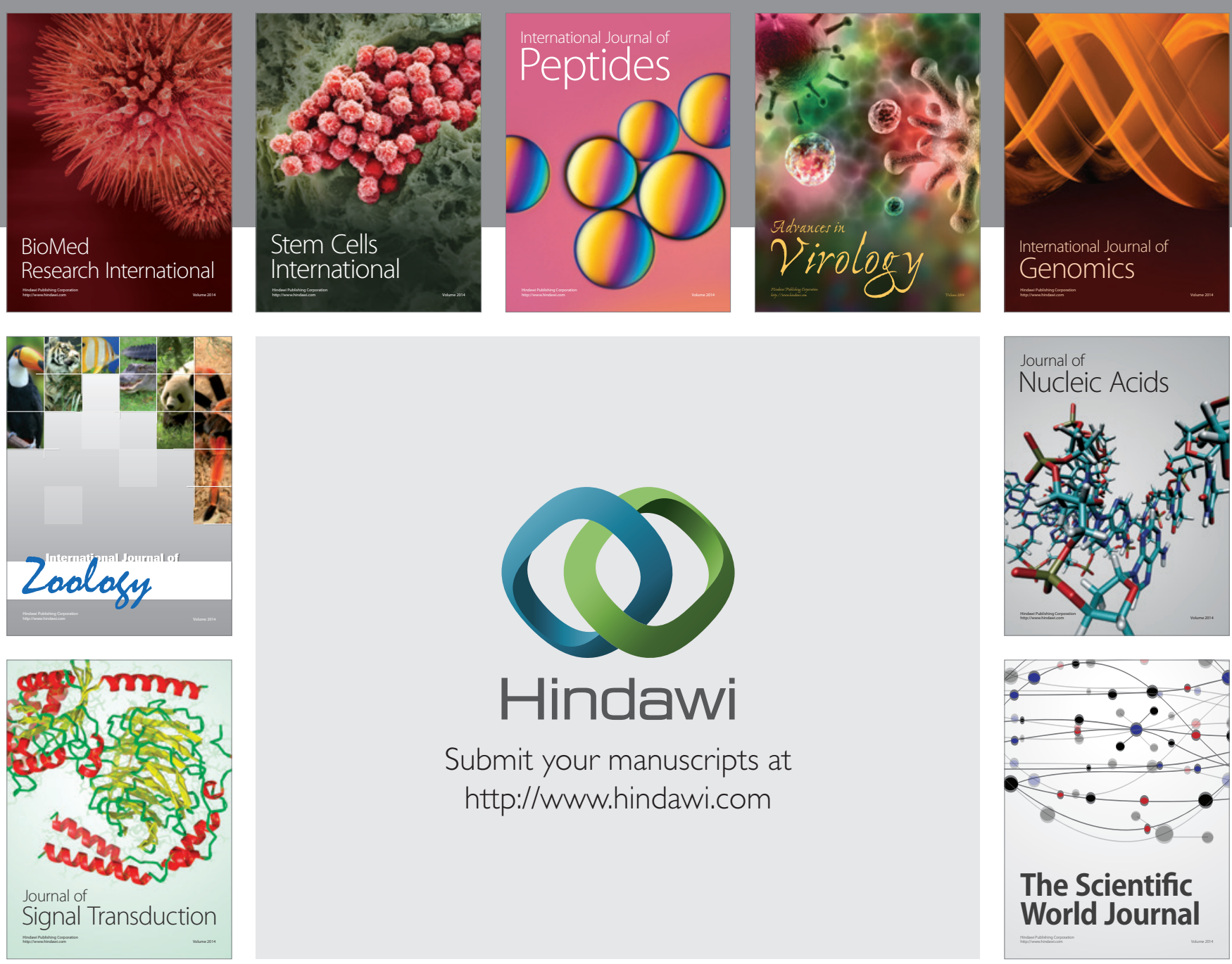

Submit your manuscripts at

http://www.hindawi.com
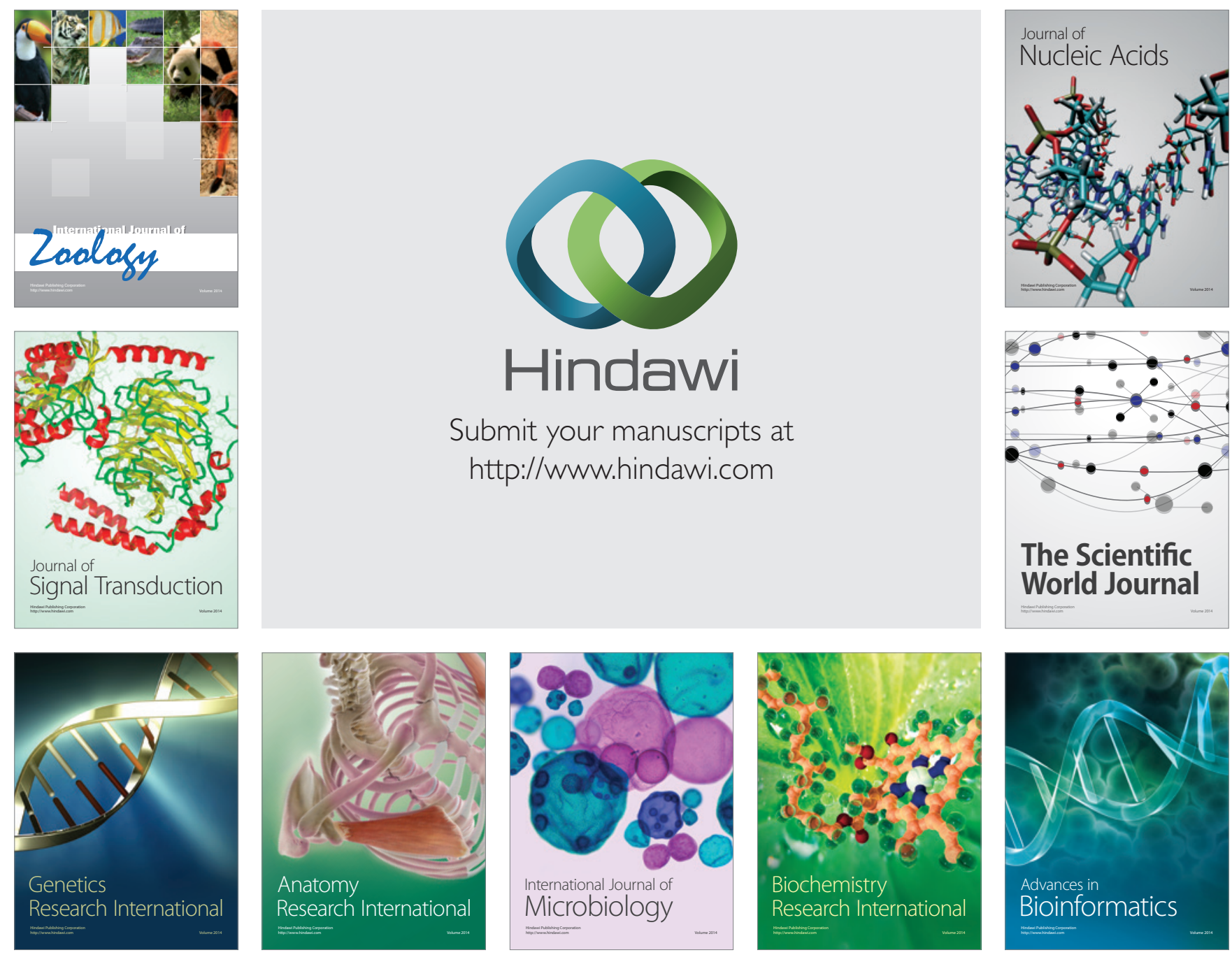

The Scientific World Journal
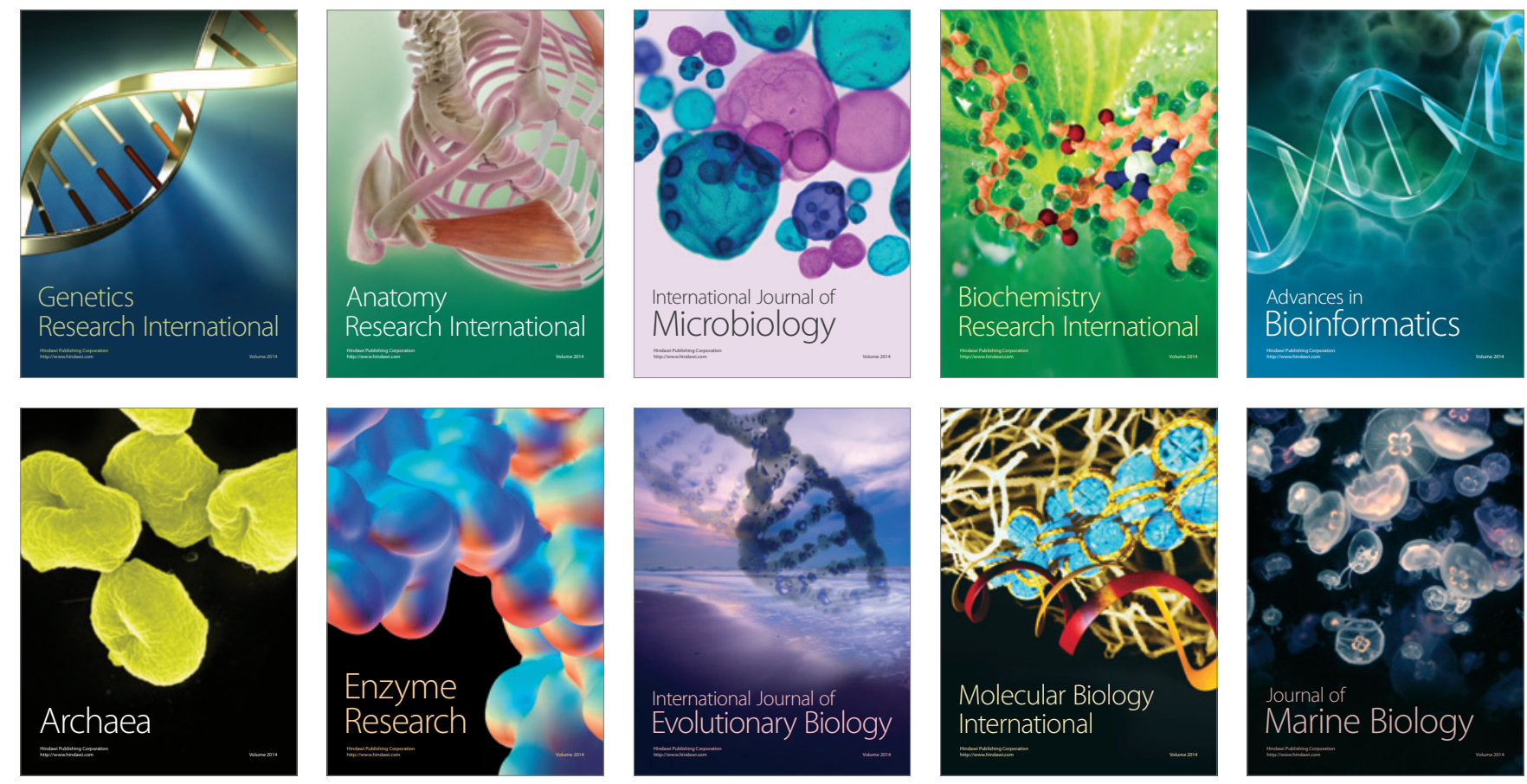